\title{
Studies on Sino-Indian Relation in Asia Regionalization
}

\author{
Yao Chaocheng1, Cui Likun² \\ ${ }^{1}$ The Shaanxi Institute of International Trade \& Commerce, Xianyang, China \\ ${ }^{2}$ Tibet University for Nationalities, Xianyang, China \\ Email: yaochaocheng@vip.sina.com
}

Received 12 August 2015; accepted 3 November 2015; published 6 November 2015

Copyright (C) 2015 by authors and Scientific Research Publishing Inc.

This work is licensed under the Creative Commons Attribution International License (CC BY). http://creativecommons.org/licenses/by/4.0/

(c) (i) Open Access

\begin{abstract}
The concurrent regional cooperation in Asia is going on in a strong trend. China and India, the two Asian giants, are actively participating in the process, both playing important roles. The two are the two most populous countries and fastest growing major economies in the world. Through the resultant growths, their political and economic influence has increased the significance of the bilateral relationship. However, following Prof. Samuel Huntington's paradigm of “Clash of Civilizations" in 1996, Dr. Daniel Twining, a British scholar, in 2005 negatively predicated that economically Asian nations may go together, but socially and politically shall still be divided from each other (Twining, 2005). The Asian regional unification course requires not only economic integration, but also political and social cooperation and coordination. India and China have had relations for more than $\mathbf{2 0 0 0}$ years, but the modern relationship still reflects complexity. In the paper, the Sino-India relationship shall be studied in ranges of economics, cultures and ideologies in frame of the Asia regionalization.
\end{abstract}

\section{Keywords}

Asian Economic Integration, India, China, Relation

\section{Historical Relations of China and India}

Being the world's two oldest civilizations and neighbors, China and India have had more than 2000 years of cultural exchanges. In Asoka Period (273-232 BC) India, Hinayana Buddhism was introduced into China (Yunnan Province) via Ceylon and Burma. Then the Mahayana Buddhism was introduced along the Silk Road into central China. China monk FA Xian visited India in $402 \mathrm{AD}$ and lived there for 10 years. He brought back to China many Sanskrit Buddhist scriptures and translated them into Chinese. In 629 AD, Tang Seng (Xuan Zang) started his long and hard journey of 50,000 km to India, via Xinjiang, Aghuganistan, Pakistan for about two 
years. He spent 16 years in India learning and teaching Buddhism. When returning to China, he brought back 657 volumes of Buddhist books in Sanskrit (Backus, 2002).

India monk Kumarajiva was invited to China in $401 \mathrm{AD}$, and the Sutra was translated into Chinese then and that is still valuable nowadays. In the 5th century, India monk Bodhi Damour became the first Zen master in the Shaolin Temple, China. The White Horse Temple in north-east Luoyang City, Henan Province, China, was built with technical consultancy of Indian monks in 75 AD. The earliest India Buddhist missionaries Dharmaratna and Molten were teaching in the temple (Tan Chung, 1998). To commemorate the historical tie, Indian Government donated funds to build an Indian style Buddhist temple in the original location, in city of Luoyang.

The bilateral trade began as early as in $600 \mathrm{BC}$ when the silk made in China was sold in India. The trading went through $300 \mathrm{AD}$ together with cultural exchange, reaching to high tide in the years of 618-907 AD, TANG Dynasty (Tan Chung, 1998). While the Buddhism declined in India and in period of Colonist expansion, the bilateral cultural exchange declined.

The bilateral cultural and economic relations date back to ancient times. The Silk Road not only served as a major trade route between India and China, but also is credited for facilitating the spread of Buddhism from India to East Asia. During the 19th century, China's growing opium trade with the British Raj triggered the First and Second Opium Wars. During World War II, India and China played a crucial role in halting the progress of invasion of the Imperial Japan (Williams, 2004).

\section{The Concurrent Bilateral Relation}

In modern era, a historical event occurred in China was that in April 1924, India poet, Asia's first Nobel literature prize winner Rabindranath Tagore came to Shanghai, China. He had visited cities of Hangzhou, Nanjing, Beijing, Taiyuan and Wuhan for giving lectures. Tagore was warmly welcomed by Chinese scholars. Another historical event happened in India was that, under guidance of Tagore, Prof. Dr. TAN Yunshan set up school of China Studies affiliated with International University of India in 1937. In 1938, India government dispatched a medical team (inc. Dr. Dwarkanath Kotnis) to China to help Chinese to fight against Japanese invaders. In the year of 1939-1940, China's great artist XU Beihong visited India.

China and India are separated by the formidable geographical obstacles of the Himalayas, sharing today a border along the Himalayas with Nepal and Bhutan acting as buffer states. Parts of the disputed Kashmir region claimed by India are also claimed and administered by either Pakistan (Azad Kashmir and Gilgit and Baltistan) or by the PRC (Aksai Chin). The Government of Pakistan on its maps shows the Aksai Chin area as mostly within China and labels the boundary "Frontier Undefined" while India holds that Aksai Chin is illegally occupied by the PRC. China and India also dispute most of Arunachal Pradesh at the far eastern end of the Himalayas. However, both countries have agreed to respect the Line of Actual Control there; the area just north of Tawang is seen as a potential flashpoint (Antony, 2009).

Therefore, the relations between contemporary China and India in the years of 1960-1990 had been characterized by border disputes, resulting in three major military conflicts- the Sino-Indian War of 1962, the Chola incident in 1967, and the 1987 Sino-Indian skirmish (Rubin, 1990). However, since the late 1980s, both countries have successfully attempted to reignite diplomatic and economic ties. In 2008, China emerged as India's largest trading partner and the two countries have also attempted to extend their strategic and military relations.

Despite growing economic and strategic ties, there are several hurdles for India and China to overcome in order to establish favorable relations. Though bilateral trade has continuously grown, India faces massive trade imbalance heavily in favor of China. The two countries have failed to resolve their long-standing border dispute and Indian media outlets have repeatedly reported Chinese military incursions into Indian territory. Both nations have steadily established heavy military infrastructure along border areas. Additionally, India remains wary about China's strong strategic bilateral relations with Pakistan, while China too has expressed concerns about Indian military and economic activities in the disputed South China Sea.

In June 2012, China stated its position that "Sino-Indian ties" could be the most "important bilateral partnership of the century". In that month Wen Jiabao the former Premier of China, and Manmohan Singh the former Prime Minister of India, set a goal to increase bilateral trade between the two countries to US\$100 billion by 2015 (Indian Embassy Web, 2013). According to a 2013 BBC World Service Poll, 36\% of Indians view China positively, with $27 \%$ expressing a negative view, whereas $23 \%$ of Chinese people view India positively, with $45 \%$ expressing a negative view (BBC, 2013). 
Though having economic cooperation and cultural exchanges, the two countries have ideological difference. Being a developing nation of democracy, politically India is weighted in favor of her western allies.

\section{The Asian Regional Economic Integration Process}

Presently, regional cooperation in Asia is going on in a strong trend. The ASEAN, with her more than five decades experience for regional cooperation, is playing important role as an axle in the regional economic unification. China, India, Japan and Korea all go for FTA negotiations and arrangements with the ASEAN. So far, China has signed FTA agreement with 12 nations including the ASEAN, Singapore, Korea and Pakistan. "One Belt and One Road” strategy (Mo Hong’e, 2015) proposed by China may further promote the Asian economic integration. The Negotiations for the TPP—which involves the US and 12 other Asian-Pacific countries including Japan and Australia could be concluded in near future.

India, the largest economy in south Asia, had been making active efforts to join in the regional economic cooperation in eastern Asia since 1990s. India’s recent performance indicates that the nation shall play more important role in Asian economic unification process. While the bilateral relation expecting to be improved as a result, India and China will continue to compete for influence in the region. This is evidenced by the fact that India’s Prime Minister Narendra Modi will soon launch a new initiative to compete with China's Maritime Silk Road (MSR) plan, known as Project Mausam (Pillalamarri, 2015). Even India is interested in potentially joining the MSR, as the plan is a boon to the economies of the entire region. However, India has to look out for its own strategic interests, since India is uniquely placed to play a major role in Indian Ocean security and trade. India’s location and power can serve to organize the states of the Indian Ocean littoral. Project Mausam would allow India to reestablish its ties with its ancient trade partners and re-establish an "Indian Ocean world" along the areas of the Indian Ocean. This world would stretch from east Africa, along the Arabian Peninsula, passing southern Iran to the major countries of South Asia and thence to Sri Lanka and Southeast Asia.

In December 2005, the East Asia Summit had been held in Kuala Lumpur, Malaysia, participating by 10 ASEAN Nations, China, Japan, Korea, India, and two non-Asian nations Australia and New Zealand. Since 2011, US and Russia were also invited to attend the Summit. On March 28, 2015, in the Boao Asian forum, Mr. Badawi, the former Malaysian Prime-Minister announced that the ASEAN Community shall be formed by Dec. 31, 2015 (Chung, 2015). It may take longer time, however it can be foreseen that the Asian Economic Community shall be in shape in the near future.

Figure 1 shows the present realistic situation of Asian-Pacific economic integration mainly promoted by China (One Belt, One Road), by US (TPP) and by India (Project Mausam), but with ASEAN as an axle, participating by Japan and South Korea. This may further develop into the future Asian-Pacific FTA.

\section{The Two Emerging Powers}

When entering the new century, the world is moving on in three basic changing trends: the change of population centers and economic centers; the perversion of advanced production methodology and political \& social structures; the change of the international political order. The three trends reveal that a few non-western nations will be emerging as the world superpowers. China carries most potentialities among them. China's pragmatic opening \& reform policy since 1978 made her economy recovering quickly. After 37 years, China now is the No.2 economic power in the world after the US.

The Economy of India is the seventh-largest in the world by nominal GDP and the third-largest by purchasing power parity (PPP). The country is one of the G-20 major economies, a member of BRICS and a developing economy among the top 20 global traders. According to the Indian Finance Ministry, the annual growth rate of the Indian economy is projected to have increased to $7.4 \%$ in $2014-15$ as compared with $6.9 \%$ in the fiscal year 2013-14. In an annual report, the IMF forecasts that the Indian Economy would grow by $7.5 \%$ percent in the 2015-16 fiscal year, even overtaking China’s annual growth rate (Runckel, 2013). Since the economic liberalization of 1991, India's GDP has been growing at a higher rate.

Curves in Figure 2 made based on above-mentioned figures are showing the growth rates of China and India from 2010 to 2015.

According to ADB Report on Asian Economic Anticipation published on August 2, 2014, total Asian GDP taking share of the world total shall be increasing from present $27 \%$ up to 52\% by the year of 2050 (Harner, 2015). 


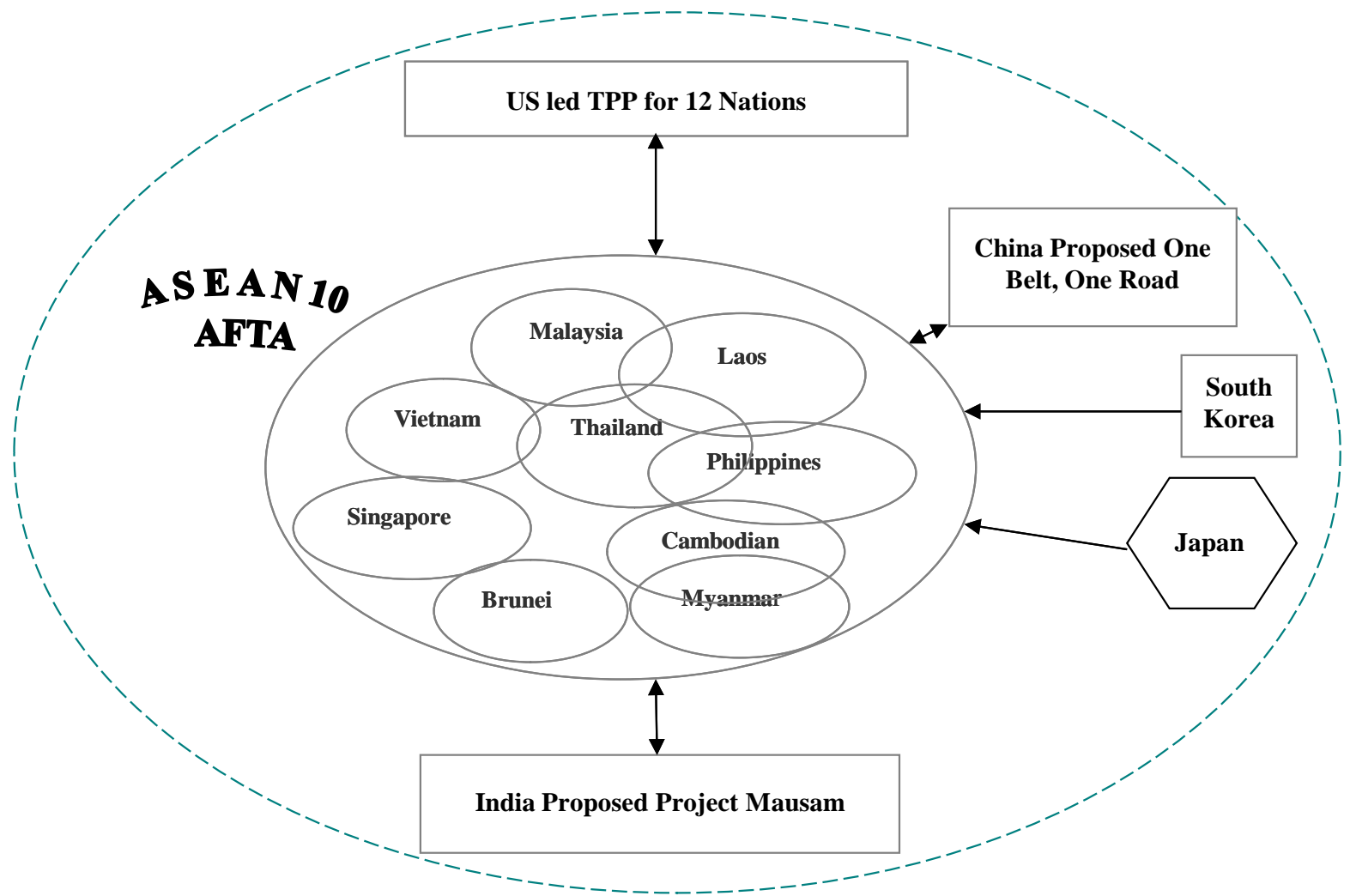

Figure 1. The initial model of future Asian-Pacific FTA.

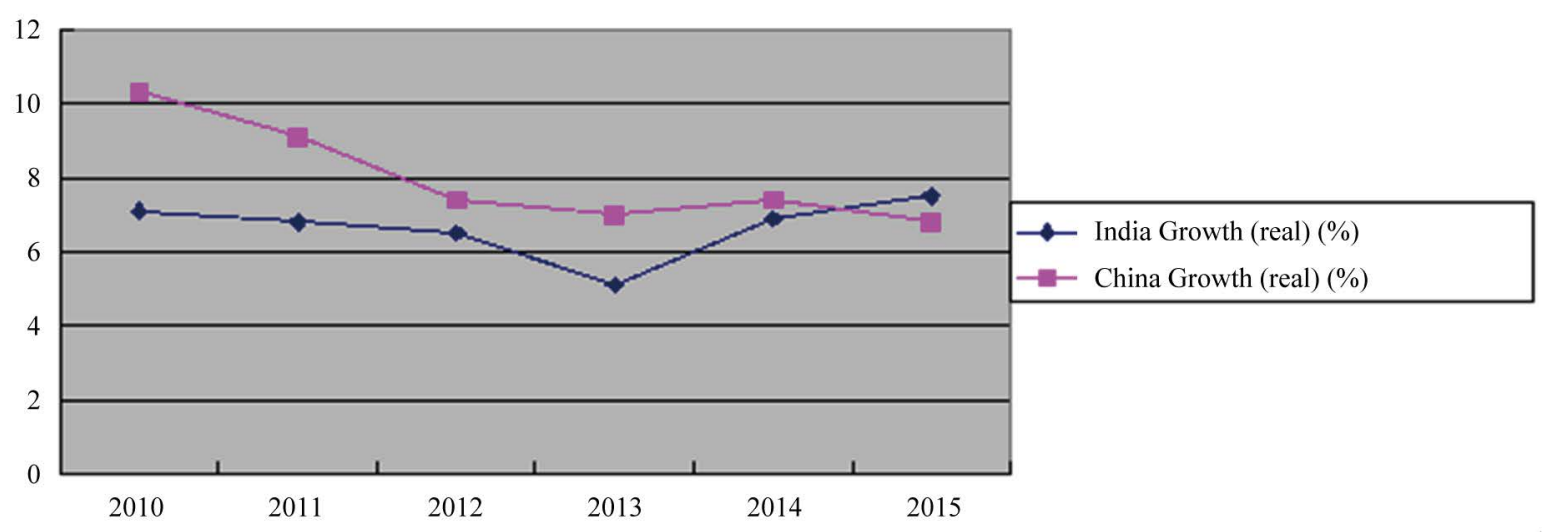

Figure 2. Growth rates of China and India 2010-2015.

Graph in Figure 3 is made to show Steghen Harner's predict that, if China and India could keep on the growth rates, their weights taken in world total GDP shall respectively be $20 \%$ and $16 \%$, both surpassing that of the US only taking $12 \%$ by 2050 .

In long term, India's economic growth rate overtakes that of China is inevitable in long run and the growth shows a tendency. Reason is simple. India has valuable human capital, people under age 35 taking $65 \%$ of the total population that shall enable India becoming the world factory replacing China (Zhao Youbin, 2015).

\section{China and India, Changing the World Structure}

The rise of China and India as major world powers promises to test the established global order in the coming decades. As the two powers grow, they are bound to change the current international system-with profound 

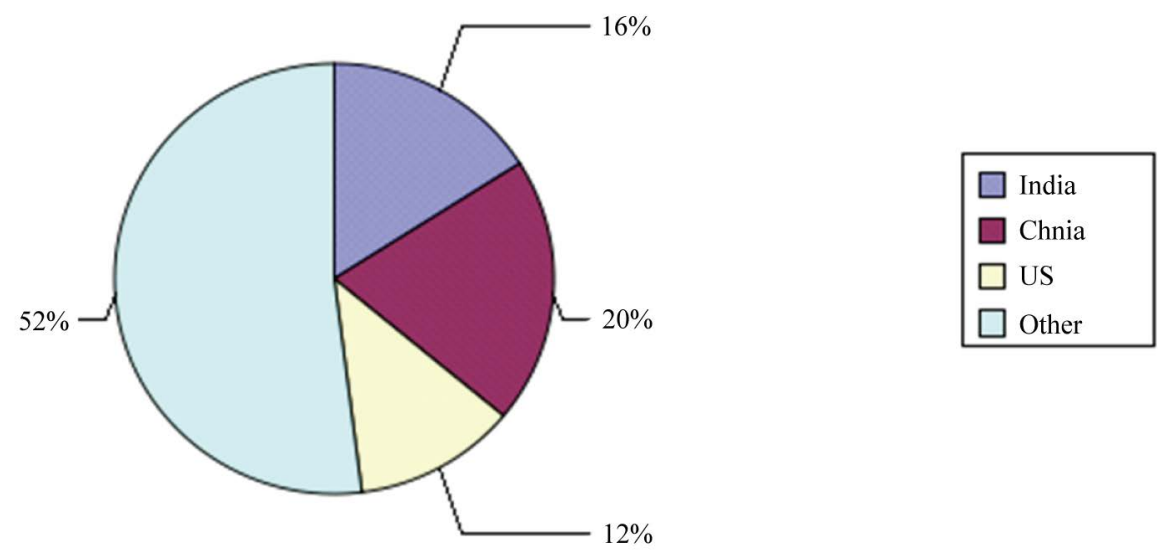

Figure 3. Graphic showing the GDP weights of China, India and US by 2050.

implications for themselves. For the United States and the world, whether they agree or not on the changes to be made, especially when coming to their relationship with the West, the two nations will influence the system's future character.

China and India's sustained economic growth fuels their increasing geopolitical and military influence. Despite their developmental similarities, China and India's bilateral strategic rivalry means that they have competing priorities on most major global issues. Sino-Indian differences are considerable on issues relating to the nonproliferation system, Asian security, regional stability in Southern Asia, and security in the maritime commons, space, and cyberspace. The two rising powers broadly agree on matters relating to the international economic system, energy security, and environment. Because of its ongoing shift to the Asia-Pacific and status as the only global superpower, the United States must manage a complex set of relationships with China and India, which are at times working at cross-purposes.

Although China has been re-positioned herself as an equal partner in regional and international cooperation substituting the erstwhile Cold War position as the leader of the third world. Under the new policy, China is trying to act as a promoter in the regional unification process, but not a leader, accepting the ASEAN as the center of the regional cooperation structure. However, the rising socialist China inevitably makes some other nations especially her neighbors worried about. In 2014, China's annual foreign trade volume reached USD 4 trillion, whereas that of US was 3.9 trillion. In the same year, China replaced US to have been the No.1 for receiving the FDI of USD 128 billion. In the past 10 years, China's FDI invested overseas increased 11 times, whereas that of US was increased four-thirds only (Hu Zuliu, 2015). China has now the third largest military power in the world. The nature of the country's political system, i.e. the immediate effective of decision making, can be even more powerful. This has made that some nations in the world, especially some Asian nations, fear that China will rise to become a threatening superpower and a challenging force to the international order. Much like China, economic interests have had a strong impact on India's involvement in the Asia-Pacific region. It is that neither country remains confined to their geographic perimeters, and both countries confront pressing demands for natural resources and energy that push them to seek solutions farther afield.

In market economic era, the competition is normally necessary, but cooperation is the only way for two countries to go with other Asian nations. Therefore, a middle solution is that China goes for regional social and economic cooperation in Asia through collective leadership with India coordinating with other Asian partners. India's emerging and participating in the collective leadership joining hands with China and Japan in Asian regional unification process shall put impact upon the geopolitical power structure of the Asia, and cooperating with US and EU making a true multi-polar world.

\section{Conclusions}

According to Samuel Huntington, after the Cold War, the fundamental cause of international conflicts shall no longer be the ideological difference, but the clashes of civilizations (Huntington, 1996). I personally believe that, the differences between the civilizations and ideologies of India and China shall still be troubling the bilateral relations. In fact, it should not be regarded as too abnormal. In the open and democratic regional unification of 
long course, there will be disputes and conflicts occurring continuously among participating nations. Yet the unification may provide a dynamic platform for democratic exchanges and peaceful negotiations within the framework of international laws for the common good. The tension between particular interests and regional or universal benefits will keep the unification process open-ended as a necessary condition for steady improvement. A regional unification even demands continuous incompleteness of any endeavor to keep development in a dialectical state for constructive opposition and consensus building. The disputes can obstruct the regional unification process, but they can be resolved somehow. India's emerging shall make the situation in balanced manner, reducing the pressures and fears of other smaller Asian nations.

The nations seeking higher social and economic efficiency by participating in the Asian regional economic unification will have to conform to the international norms and standards. The Asian economic unification as a peace and democratic process will no doubt accelerate China's political reform. This will certainly help China to grow to a strong and solid pier of world peace.

Learning from Europe, India and China should try to improve their relationship with more tolerance and magnanimity. If these two nations could get rid of the historical resentments and unite as Germany and France did, the Asian economic unification process will achieve velocity and gravity. The European experience is revealing clearly that Asians have to have a new way of thinking and a looking forward attitude to deal with the non-economic obstacles, cooperating socially and politically. To realize the unification, Asia must build not only an efficiently integrated economy, but also a big Asian family with sustained peace.

\section{References}

Antony, A. K. (2009). China-Pakistan Military Links Upset India. Financial Times.

Backus, M. (2002) Ancient China. Lorenz Educational Press, Dayton.

BBC (2013) World Service Poll. BBC, 22 May 2013.

Chung, C. V. (2015). Asian Energy, Resources Partnership. Boao Forum Conference, New China.

Harner, S. (2015). By the 2050, Asia’s GDP Output Shall Take Half of the World Total. Japan Enonomy, 3 August 2015.

Hu Zuliu (2015). China Becomes the Largest Economy in Asia, Phoenix Finance.

Huntington, S. P. (1996). The Clash of Civilizations and Remaking of the World Order. Touchstone Book, Simon \& Schuster Inc.

Indian Embassy, Beijing. India-China Bilateral Relations-Historical Ties. http://www.indianembassy.org.cn/DynamicContent.aspx?MenuId=1\&SubMenuId $=0$

Mo Hong’e (2015). “One Belt, One Road” Projects Get Approval. CNWeb.

Pillalamarri, A. (2014). Project Mausam: India’s Answer to China’s “Maritime Silk Road”. The Diplomat.

Rubin, A. P. (1970). The Sino-Indian Border Disputes. International and Comparative Law Quarterly, 9.

Runckel, C. W. (2013). Crux of Asia: China, India, and the Emerging Global Order, Business-in-Asia.

Tan Chung (1998). A Sino-Indian Perspective for India-China Understanding. http://ignca.nic.in/ks_41019.htm

Twining, D. (2005). An Overview on China. The Financial Times, 22.

Williams, B. (2004). World War Two. Twenty-First Century Books, USA.

Zhao Youbin (2015). Nine Reasons for India Overtaking China. The Phoenix Finance. 